\title{
Occupations of fathers of patients with Wilms's
} tumour

\author{
ARLENE F. KANTOR, ${ }^{1}$ MARY G. MCCREA CURNEN, ${ }^{2} \mathrm{~J}^{\text {. WISTER MEIGS, }}{ }^{3}$ AND \\ JOHN T. FLANNERY ${ }^{4}$ \\ From the ${ }^{1}$ Environmental Epidemiology Branch, National Cancer Institute, National Institutes of Health, \\ Bethesda, Maryland, the ${ }^{2}$ Division of Epidemiology, Columbia University School of Public Health, New York, \\ the ${ }^{3}$ Connecticut Cancer Epidemiology Unit, New Haven, Connecticut, and the ${ }^{4}$ Connecticut Tumor Registry, \\ Connecticut State Department of Health, Hartford, Connecticut
}

SUMmaRY A case-control study of 149 Connecticut-born children with Wilms's tumour reported to the Connecticut Tumor Registry during the period 1935-1973 and of 149 matched controls was undertaken in order to explore the possibility that children with Wilms's tumour may have been exposed perinatally to carcinogenic agents. The occupation of the father at the time of the child's birth was investigated and used as an indicator of potential sources of carcinogens to which infants in the study may have been exposed. An association was found between paternal occupations related to lead in the group developing Wilms's tumour compared with the controls.

The fact that most cases of Wilms's tumour, a childhood neoplasm of the kidney, are diagnosed before the age of four suggests that factors operating at the time of conception, during pregnancy, or soon after birth may be important in the aetiology of this neoplasm. A genetic predisposition to the disease has been reported, as well as an association with several congenital malformations, particularly aniridia and hemihypertrophy (Miller et al., 1964; Knudson and Strong, 1972; Pendergrass, 1976).

Little information is available on specific environmental factors that may influence the occurrence of Wilms's tumour. Fabia and Thuy (1974) studied the occupations of fathers at the time of birth of children who died of neoplasms. They found an excess of hydrocarbon-related occupations in fathers of children who developed cancer but not among the fathers of the few patients in their series with Wilms's tumour. In a subsequent study, Hakulinen et al. (1976) found no relation between father's occupation and childhood cancer; cases of Wilms's tumour were not analysed separately.

The hypothesis that perinatal exposure to carcinogens may be associated with the subsequent occurrence of Wilms's tumour was tested in this study of children who entered the Connecticut Tumor Registry during a 38-year period.

\section{Material and methods}

All 149 patients with a diagnosis of Wilms's tumour, who were born in Connecticut and reported to the Connecticut Tumor Registry during the 1935-1973 period, were entered in this study (80 males and 69 females). Cases ranged in age from the newborn to 19 years; 133 were white and 16 were black. Bilateral involvement was reported in two patients. The 149 controls were selected from the Connecticut State Health Department files of birth certificates and matched with the cases for sex, race, and year of birth. No cancers were found among the controls. Information on cases and controls, obtained exclusively from birth certificates, included the occupation of the father. The classification of occupations was similar to that employed by Fabia and Thuy (1974) and Hakulinen et al. (1976). Table 1 lists the 22 broad groups of occupations which were used in this study. Among them, six occupations are known to have considerable exposure to hydrocarbons and seven to lead, a major additive to petrol, also present in car exhaust fumes. The occupations-dyer, miner, lumberman, and painter-included as hydrocarbon-related by Fabia and Thuy (1974) and Hakulinen et al. (1976) were not represented in our study. 
Table 1 Distribution of children with Wilms's tumour and controls according to occupation of father at time of birth

\begin{tabular}{|c|c|c|}
\hline Occupation & Cases & Controls \\
\hline 1. Professional, administrator ......................... & 26 & 26 \\
\hline 2. White collar worker .................................... & 22 & 25 \\
\hline 3. Farmer & 1 & 8 \\
\hline 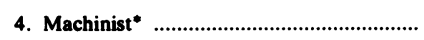 & 5 & 3) \\
\hline 5. Cleaner ${ }^{*}$ & 2 & 1 \\
\hline 6. Embalmer & 0 & 1 \\
\hline 7. Driver $\dagger^{*}$ & 8 & 4 \\
\hline 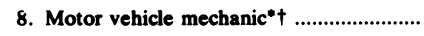 & 6 & 1 \\
\hline 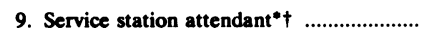 & 3 & 0 \\
\hline 10. Welder f $^{\prime}$ & 3 & 220 \\
\hline 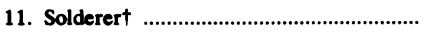 & 1 & 0 \\
\hline 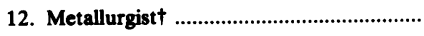 & 1 & $\mathbf{0}$ \\
\hline 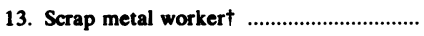 & $\mathbf{0}$ & 1 \\
\hline 14. Factory worker, not elsewhere classified & 32 & 33 \\
\hline 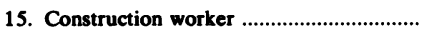 & 1 & 2 \\
\hline 16. Electrician, plumber, carpenter ................. & 7 & 10 \\
\hline 17. Tailor, weaver, furrier, shoemaker .......... & 4 & 3 \\
\hline 18. Butcher, dairy worker, cook ....................... & 2 & 2 \\
\hline 19. Other miscellaneous blue collar ............... & 10 & 10 \\
\hline 20. Unknown & 9 & 9 \\
\hline 21. Unemployed, student ................................. & 0 & 4 \\
\hline 22. Armed Forces & 6 & 6 \\
\hline TOTAL & 149 & 149 \\
\hline
\end{tabular}

- Hydrocarbon-related occupation.

t Lead-related occupation.

In order to assess the comparability of cases and controls, other maternal and paternal factors entered on the birth certificates (mother's pregnancy history, parent's age and place of birth, child's birthweight, and length of gestation) were examined and found to be similar in these two groups. MacMahon and Newill (1962) also reported that birth characteristics of children dying of malignant neoplasms did not differ from those of controls.

In the case-control comparison of birth certificate variables, the $\chi^{2}$ test for paired observations and the Student's $t$ statistic for paired samples were used. The McNemar test on a dichotomous outcome from matched pairs, incorporating Fisher's exact probability, was used instead of the $\chi^{2}$ test if one of the off-diagonal frequencies in the resulting $2 \times 2$ table was less than five. Estimates of odds ratios and their confidence intervals were calculated according to the method for individually matched series as described by Miettinen (1970).

\section{Results}

The distribution of children with Wilms's tumour and matched controls according to their fathers' occupations at the time of birth is shown in Table 1 . The distribution of both groups was similar for offspring of professionals and administrators, and of white collar workers, suggesting that cases and controls were comparably distributed by social class (Hollingshead, 1957).

Both cases and controls had similar distribution of urban and rural births: thus the larger number of farmers among fathers of controls cannot be explained.

Fathers of 24 Wilms's tumour patients and 10 controls were in occupations considered to be hydrocarbon-related, yielding an odds ratio of 2.4 $\left(X^{2}=4.97 ; P=0.026 ; 95 \%\right.$ confidence interval 1.1 to $5 \cdot 7)$.

The excess among the case group of fathers employed in hydrocarbon-related occupations was contributed largely by occupations with exposure to petrol and its combustion products, that is, driver, motor vehicle mechanic, and service station attendant, where exposure to lead is known to occur.

Fathers of 22 Wilms's tumour cases and of six controls were found to be in lead-related occupations (driver, motor vehicle mechanic, service station attendant, welder, solderer, metallurgist, and scrap metal worker) as seen in Table 1 . The resulting odds ratio is $3.7\left(\chi^{2}=8.04 ; \mathrm{P}=0.005 ; 95 \%\right.$ confidence interval 1.5 to $11 \cdot 1)$.

Odds ratios calculated in Table 2 show that exposure to lead yields the highest risk of Wilms's tumour.

Thirteen fathers of cases and five fathers of controls who were in lead-related occupations were parents of older children born in Connecticut.

Table 2 Odds ratios for hydrocarbon- and lead-related occupations

\begin{tabular}{|c|c|c|c|}
\hline \multirow[b]{2}{*}{ Occupational exposure } & \multicolumn{2}{|c|}{ Number of fathers } & \multirow[b]{2}{*}{ Odds ratio } \\
\hline & Cases & Controls & \\
\hline Lead exposure only & 5 & 1 & $5.00(5.75)^{*}$ \\
\hline Hydrocarbon exposure only .................... & 7 & 5 & $1.40(1.61)$ \\
\hline Both lead and hydrocarbon exposure. & 17 & 5 & $3.40(3.91)$ \\
\hline Neither exposure & 120 & 138 & $0.87(1.00)$ \\
\hline
\end{tabular}

- Number in parentheses represent odds ratio for this exposure divided by odds ratio for neither exposure. 
Information from the birth certificates of these earlier offspring indicated that $11(85 \%)$ and two $(40 \%)$ respectively reported the same lead-related occupation at the time of birth of the elder siblings (the average time between births of these two offspring was 4.5 years in the case group and 2.3 years in the control).

There were no reports of multiple primaries (other than bilateral involvement) among Wilms's tumour patients in the Connecticut Tumor Registry. Cancers in siblings occurred in the families of five cases, none in families of controls. Two siblings developed Wilms's tumour. All other cancers in siblings were diagnosed after the birth of the Wilms's tumour index case. None of the five fathers of siblings with cancer were employed in hydrocarbon- or lead-related occupations. Cancer occurred in the offspring of one male and one female patient with Wilms's tumour: the fathers of these two index cases were not employed in hydrocarbon- or lead-related occupations. The father of one of the two children with bilateral Wilms's tumour was employed in a hydrocarbon-lead-related occupation.

\section{Discussion}

In this study a significantly greater number of fathers of children with Wilms's tumour were in lead-related occupations as compared with controls (odds ratio $=3 \cdot 7$ ). As was mentioned earlier, only hydrocarbon-related occupations have been reported more frequently among fathers of children with cancer than controls, but not among fathers of children with Wilms's tumour.

In the United States of America, the average 'normal' blood-lead levels have ranged from $0.014 \mathrm{mg} / 100 \mathrm{ml}$ in rural areas to $0.022 \mathrm{mg} / 100 \mathrm{ml}$ in urban areas (Hofreuter et al., 1961). Welders, solderers, metallurgists and scrap metal workers are likely to have mean blood-lead levels of $0.040 \mathrm{mg} / 100 \mathrm{ml}$ or above. They are at a high risk of lead poisoning (that is, blood-lead exceeding $0.08 \mathrm{mg} / 100 \mathrm{ml}$ ) (Raymond et al., 1960; Bustelo, 1962; Benevenuti, 1972). The mean blood-lead level in garage mechanics has been found in several studies to be about $0.035 \mathrm{mg} / 100 \mathrm{ml}$ (Hofreuter et al., 1961; Tola et al., 1972); this finding may be explained in part by the fact that many greases contain lead naphthenate which can be absorbed through the skin (Hine et.al., 1969). Service station attendants have been reported to have mean blood-lead levels higher than $0.030 \mathrm{mg} / 100 \mathrm{ml}$ (Kehoe et al., 1969; Moore et al., 1976). Motor vehicle drivers have been found to have on the average blood-lead levels $10 \%-15 \%$ lower than service station attendants but $30 \%$ higher levels than other urban residents (Haag, 1975).
Lead appears to have the capacity to cause chromosomal changes after short exposures to relatively small doses, and at blood-lead levels long considered compatible with normal physiological function. Cultured lymphocytes of workers whose blood-lead levels rose from 0.034 to $0.045 \mathrm{mg}$ $\mathrm{Pb} / 100 \mathrm{ml}$ after a month of increased lead exposure have shown doubling of the percentage of abnormal metaphases (Forni et al., 1976). These increased numbers of chromosomal abnormalities persisted for several months when blood-lead remained above $0.040 \mathrm{mg} / 100 \mathrm{ml}$. Some reversal of these changes was observed after a few weeks away from lead exposure. Teratospermia has been observed to range from $16 \%$ to $86 \%$ among men with occupational exposures to lead, in linear association with blood-lead levels ranging from 0.023 to $0.075 \mathrm{mg} / 100 \mathrm{ml}$ (Lancranjan et al., 1975).

The two-step mutation process, proposed by Knudson and Strong (1972) to explain Wilms's tumour, states that the first mutation may be a germinal (prezygotic) or a somatic event. It seems reasonable to assume that an effect of lead on spermatogenesis at the time of conception may be a prezygotic event that could play a role in the aetiology of Wilms's tumour.

Since it has been established that Wilms's tumour can be associated with a familial factor and with the presence of congenital anomalies, it would be useful to determine whether other renal parenchymal abnormalities associated with Wilms's tumour are found in patients whose fathers have been exposed to lead (Bove and Adams, 1976).

The percentage of patients with Wilms's tumour in this study whose fathers had been exposed to lead $(15 \%)$ is relatively low, and may suggest that this cause is only a possible explanation of a small proportion of cases.

In this study, tests for lead intoxication were not performed on children with Wilms's tumour, their parents, or the controls. In the future, such tests may provide additional evidence implicating lead as an aetiological factor in Wilms's tumour.

We thank Dr. R. Monson, Harvard School of Public Health; Dr. J. Fraumeni, Jr., National Cancer Institute; Dr. E. Curnen, Jr., College of Physicians and Surgeons of Columbia University; Dr. $\mathrm{H}$. Kantor, George Washington University Medical Center; Mrs. L. Turgeon, Columbia University School of Public Health; Mr. H. Burdo, Public Health Statistics Section of the Connecticut State Department of Health; the staff of the Connecticut Cancer Epidemiology Unit; Ms. A. Stark; Ms. J. Hooper; and Ms. C. Palmieri. 
This study was supported by Public Health Service Contracts NO1 CP 33235 and NO1 CP 43203 from the National Cancer Institute.

Reprints from Dr. Arlene F. Kantor, Environmental Epidemiology Branch, Landow Building, Room 3CO7, National Cancer Institute, National Institutes of Health, Bethesda, Maryland 20014, USA.

\section{References}

Benevenuti, F. (1972). L'inquinamento ambientale nei reparti di termosaldatura della industrie eletronich. (Air pollution in electronic appliance manufacturers' soldering shops). Securitas (Rome), 10, 861-876.

Bove, K. E., and McAdams, A. J. (1976). The nephroblastomatosis complex and its relationship to Wilms' tumor: a clinicopathologic treatise. Perspectives in Pediatric Pathology, 3, 185-223.

Bustelo, J. (1962). Saturnismo latente entre los soldadores do material he hierro galvanizado. (Latent lead poisoning among welders of galvanised iron). Medicina y seguridad del trabajo, 10, 60-63.

Fabia, J., and Thuy, T. D. (1974). Occupation of father at time of birth of children dying of malignant diseases. British Journal of Preventive and Social Medicine, 28, 98-100.

Forni, A., Cambiaghi, G., and Secchi, G. C. (1976). Initial occupational exposure to lead: chromosome and biochemical findings. Archives of Environmental Health, 31, 73-78.

Haag, E. (1975). Juris Druck und Verlag, Zurich. Unpublished thesis.

Hakulinen, T., Salonen, T., and Teppo, L. (1976). Cancer in the offspring of fathers in hydrocarbon-related occupations. British Journal of Preventive and Social Medicine, 30, 138-140.

Hine, C. H., Cavalli, R. D., and Beltran, S. M. (1969). Percutaneous absorption of lead from industrial lubricants. Journal of Occupational Medicine, 11, 568-575.
Hofreuter, D. H., Catcott, E. J., Keenan, R. G., and Zintara, C. (1961). The public health significance of atmospheric lead. Archives of Environmental Health, 3, 568-574.

Hollingshead, A. B. (1957). Two factor index of social position. Published by the author: New Haven.

Kehoe, R. A., Cholak; J., Spence, J. A., and Hancock, W. (1969). Potential hazards of exposure to lead. Archives of Environmental Health, 6, 239-254.

Knudson, A. G., and Strong, L. C. (1972). Mutation and cancer: a model for Wilms' tumor of the kidney. Journal of the National Cancer Institute, 48, 313-324.

Lancranjan, I., Popescu, H. I., Gavanescu, O. et al., (1975). Reproductive ability of workmen occupationally exposed to lead. Archives of Environmental Health, 30, 396-401.

MacMahon, B., and Newill, V. A. (1962). Birth characteristics of children dying of malignant neoplasms. Journal of the National Cancer Institute, 28, 231-244.

Miettinen, O. S. (1970). Estimation of relative risk for individually matched series. Biometrics, 26, 75-86.

Miller, R. W., Fraumeni, J. F., Jr., and Manning, M. D. (1964). Association of Wilms' tumor with aniridia, hemihypertrophy, and other congenital malformations. New England Journal of Medicine, 270, 922-927.

Moore, P. J., Pridmore, S. A., and Gill, G. F. (1976). Total blood lead levels in petrol vendors. Medical Journal of Australia, 1(13), 438-440.

Pendergrass, T. W. (1976). Congenital anomalies in children with Wilms' tumor. Cancer, 37, 403-409.

Raymond, V., Smagghe, G., and Risselin, M. (1960). Saturnisme chez les decoupeurs de gazometres. (Lead poisoning in gas cutters working on gasometers). Cahiers des Comités de prevention du batiment et des travaux publics (Paris), 15, 189-190.

Tola, S., Hernberg, S., and Nikkanen, J. (1972). Occupational lead exposure in Finland. II. Service stations. Work, Environment, Health, 9, 102-105. 